\title{
Increased sodium and fluctuations in minerals in acid limes expressing witches' broom symptoms
}

\author{
Aisha G. Al-Ghaithi ${ }^{1}$, Muhammad Asif Hanif ${ }^{2}$, Walid M. Al-Busaidi ${ }^{1}$ and Abdullah M. Al-Sadi ${ }^{*}$ (D)
}

\begin{abstract}
Witches' broom disease of lime (WBDL), caused by 'Candidatus Phytoplasma aurantifolia', is a very serious disease of acid limes. The disease destroyed more than one million lime trees in the Middle East. WBDL results in the production of small, clustered leaves in some branches of lime trees. Branches develop symptoms with time and become unproductive, until the whole tree collapses within 4-8 years of first symptom appearance. This study was conducted to investigate differences in minerals between symptomatic and asymptomatic leaves of infected lime trees. The study included one set of leaves from uninfected trees and two sets of infected leaves: symptomatic leaves and asymptomatic leaves obtained from randomly selected acid lime trees. Nested polymerase chain reaction detected phytoplasma in the symptomatic and asymptomatic leaves from the six infected trees, but not from the uninfected trees. Phylogenetic analysis showed that all phytoplasmas belong to the $16 \mathrm{~S}$ rRNA group II-B. Mineral analysis revealed that the level of Na significantly increased by four times in the symptomatic leaves compared to the non-symptomatic leaves and to the uninfected leaves. In addition, symptom development resulted in a significant increase in the levels of $P$ and $K$ by 1.6 and 1.5 times, respectively, and a significant decrease in the levels of Ca and B by 1.2 and 1.8 times, respectively. There was no significant effect of WBDL on the levels of N, Cu, Zn, and Fe. The development of witches' broom disease symptoms was found to be associated with changes in some minerals. The study discusses factors and consequences of changes in the mineral content of acid limes infected by phytoplasma.
\end{abstract}

Keywords: Metals, Mexican lime, Oman, Pathogen, WBDL

\section{Background}

Phytoplasmas are phloem limited, gram-positive bacteria in the Mollicutes class (Bové and Garnier 2002). They have been found associated with diseases in more than 700 plant species (Bertaccini et al. 2014; Hogenhout et al. 2008; Bertaccini 2007; Lee et al. 2000). Phytoplasma can cause different symptoms including phyllody, stunting, virescence, little leaf, yellowing, witches' broom, decline, and other symptoms (Hogenhout et al. 2008). They are usually transmitted by sap-sucking insects of the order Hemiptera, especially by leafhoppers, planthoppers and psyllids (Sugio et al. 2011; Ammar and Hogenhout 2006; Hill and Sinclair 2000).

\footnotetext{
*Correspondence: alsadi@squ.edu.om

${ }^{1}$ Department of Crop Sciences, College of Agricultural and Marine

Sciences, Sultan Qaboos University, Muscat, Oman

Full list of author information is available at the end of the article
}

Witches' broom disease, caused by Candidatus Phytoplasma aurantifolia, is a very serious disease of acid limes (Citrus aurantifolia). Symptoms of the disease are characterized by excessive shoot growth with very small, pale green leaves and short internodes. Witches' broom symptoms progress very rabidly on lime branches, killing trees within 4-8 years after symptom appearance (AlSadi et al. 2012; Chung et al. 2006b). The disease resulted in the death of over one million lime trees in different countries (Chung et al. 2006a; Al-Sadi et al. 2012; Bertaccini and Duduk 2009; Al-Yahyai et al. 2014b).

Several factors can predispose plants to infection by microorganisms, including mineral imbalance ( $\mathrm{McNew}$ 1953). Some diseases are severe on weakened and undernourished plants; others are more destructive when plants are growing vigorously. Plants need minerals for normal growth and development. Mineral elements play

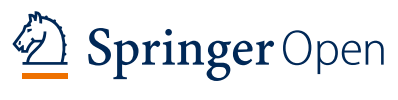

(c) 2016 Al-Ghaithi et al. This article is distributed under the terms of the Creative Commons Attribution 4.0 International License (http://creativecommons.org/licenses/by/4.0/), which permits unrestricted use, distribution, and reproduction in any medium, provided you give appropriate credit to the original author(s) and the source, provide a link to the Creative Commons license, and indicate if changes were made. 
a significant role in the physiology and metabolisms of the plant and their characterization can reveal the genetics of the plants and their interaction with biotic and environmental factors (Baxter et al. 2013, 2014). Any deficiency or excess may affect plant growth, development and production. The severity of potato scab and club rot of cabbage increased with enhanced supply of calcium $(\mathrm{Ca})$, potassium $(\mathrm{K})$ or nitrogen $(\mathrm{N})$ (McNew 1953).

Several studies have addressed the interaction between phytoplasma and their host plants. Phytoplasma have been shown to produce effectors to modulate their host plants and to overcome plant defense responses (Sugio et al. 2011; Sugio and Hogenhout 2012). Recent studies on the biochemical interactions showed that phytoplasma can affect essential oils of acid lime (Al-Yahyai et al. 2014a). A study by Rossi et al. (2010) showed Fe / $\mathrm{Mn}$ and $\mathrm{K} / \mathrm{Mg}$ imbalance in phytoplasma infected pear and apricot, respectively. Zhao and Liu (2009) showed mineral nutrient differences between healthy and phytoplasma infected jujube, while De Oliveira et al. (2002, 2005) showed reduced concentrations of $\mathrm{Mg}$ in maize tissues infected by phytoplasma. However, there are few studies on the changes in minerals in acid limes developing symptoms of Phytoplasma infection.

This study was carried out to investigate changes in minerals in acid lime leaves developing symptoms of witches' broom disease. Information on the mineral status of acid lime trees and the relationship between phytoplasma infection, symptom development and minerals concentration in plant tissues will help us understand some of the changes induced by phytoplasma in acid limes. This may help in the development of future management strategies for WBDL.

\section{Methods}

\section{Sample collection}

Leaf samples of acid lime were collected from six lime trees developing symptoms of WBDL (Al-Sadi et al. 2012) (Table 1). Two types of samples were collected from each of the six trees: $1 \mathrm{~kg}$ of leaves without any disease symptoms and $1 \mathrm{~kg}$ of symptomatic leaves which are developing typical WBDL symptoms (i.e. small clustered leaves with dense and thin branches; Fig. 1). In addition, two samples were collected from uninfected lime trees for comparison purposes. The collected samples were transported to the Plant Pathology laboratory (SQU, Oman) in a cool box. The samples were dried at $70{ }^{\circ} \mathrm{C}$, followed by grinding using a food processor (Moulinex, France) under sterile conditions. The obtained powdered materials were stored in airtight jars for further studies.

\section{Detection and identification of phytoplasma}

Total DNA was extracted from $100 \mathrm{mg}$ of the midrib from each sample following the cetyltrimethyl ammonium bromide (CTAB) method (Doyle and Doyle 1990). Primers P1 (5'-AAGAGTTTGATCCTGGCTCAGG ATT-3') (Deng and Hiruki 1991) and P7 (5'-CGTCC TTCATCGGCTCTT-3') (Schneider et al. 1995) were used in amplification of phytoplasma 16S rRNA gene, spacer region between $16 \mathrm{~S}$ and $23 \mathrm{~S}$ rRNA genes and the start of $23 \mathrm{~S}$ rRNA gene. The polymerase chain reaction (PCR) consisted of 35 cycles: denaturation at $94{ }^{\circ} \mathrm{C}$ for $30 \mathrm{~s}$ ( $2 \mathrm{~min}$ for the first cycle), annealing for $40 \mathrm{~s}$ at

Table 1 Characteristics of acid lime trees and leaf samples included in the study

\begin{tabular}{|c|c|c|c|c|}
\hline Tree code & Sample code & WBDL symptoms & $\begin{array}{l}\text { Presence } \\
\text { of phytoplasma }^{a}\end{array}$ & $\begin{array}{l}\text { Accession } \\
\text { numbers }\end{array}$ \\
\hline YS1 & YS1 & No & - & - \\
\hline YS2 & YS2 & No & - & - \\
\hline \multirow[t]{2}{*}{ D1 } & D1-A & Asymptomatic leaves & + & LN866569 \\
\hline & D1-S & Symptomatic leaves & + & LN866570 \\
\hline \multirow[t]{2}{*}{ D2 } & D2-A & Asymptomatic leaves & + & LN866571 \\
\hline & D2-S & Symptomatic leaves & + & LN866572 \\
\hline \multirow[t]{2}{*}{ B1 } & B1-A & Asymptomatic leaves & + & LN866565 \\
\hline & B1-S & Symptomatic leaves & + & LN866566 \\
\hline \multirow[t]{2}{*}{ B2 } & B2-A & Asymptomatic leaves & + & LN866567 \\
\hline & B2-S & Symptomatic leaves & + & LN866568 \\
\hline \multirow[t]{2}{*}{$\mathrm{SH}$} & $\mathrm{SH}-\mathrm{A}$ & Asymptomatic leaves & + & LN866579 \\
\hline & $\mathrm{SH}-\mathrm{S}$ & Symptomatic leaves & + & LN866580 \\
\hline \multirow[t]{2}{*}{ M1 } & M1-A & Asymptomatic leaves & + & LN866575 \\
\hline & M1-S & Symptomatic leaves & + & LN866576 \\
\hline
\end{tabular}

\footnotetext{
a Based on PCR analysis, where (+) indicates presence of phytoplasma and (-) indicating the lack of phytoplasma

b 165 rRNA sequences deposited at the European Nucleotide Archive
} 


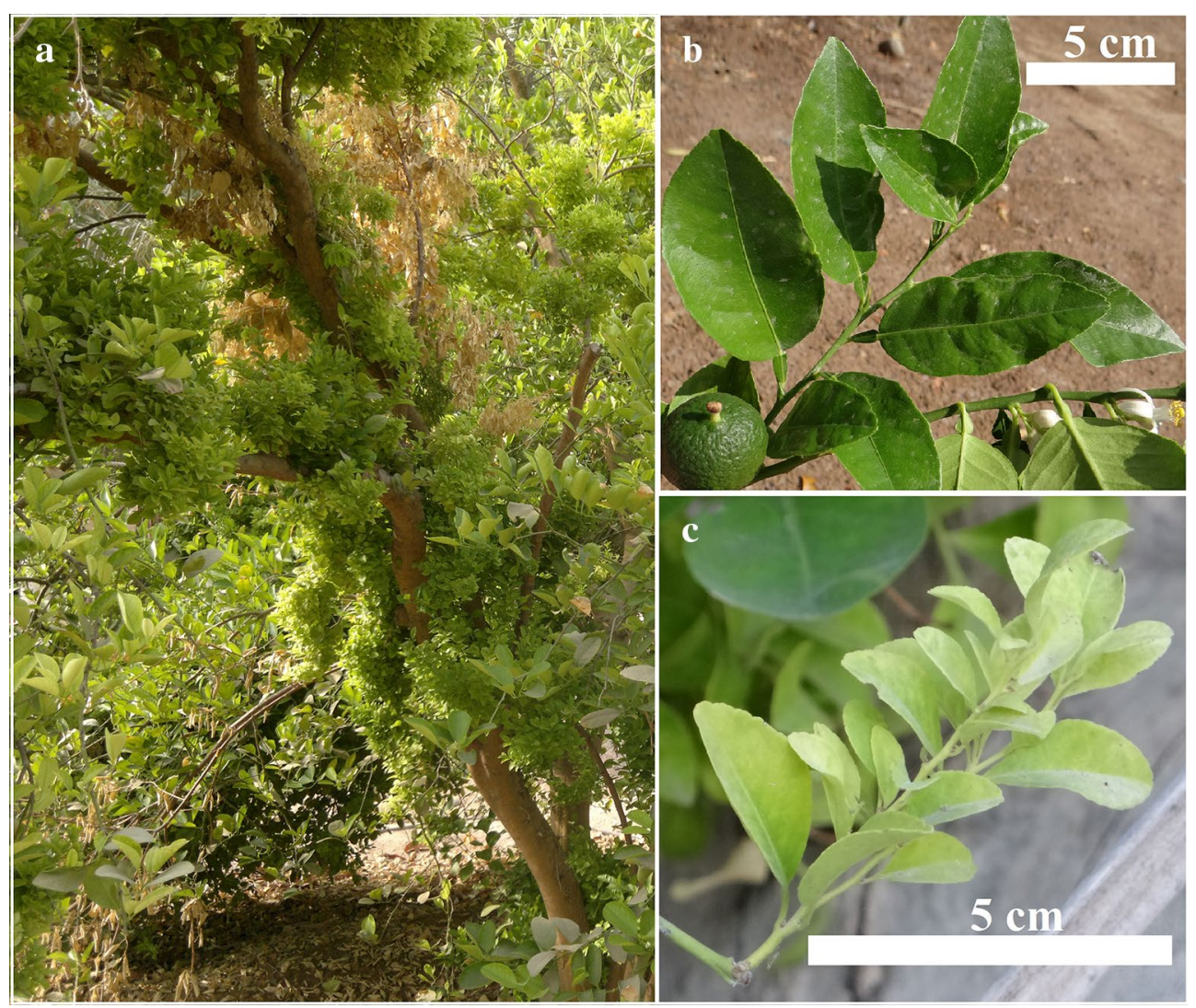

Fig. 1 Acid lime tree infected by 'Candidatus Phytoplasma aurantifolia' and developing typical symptoms of witches' broom disease (a). A close up photo of asymptomatic leaves (b) and symptomatic leaves with typical symptoms of WBDL (c smaller leaves, light green to yellow in color). The bar scale in $(\mathbf{b}, \mathbf{c})$ is $5 \mathrm{~cm}$

$60{ }^{\circ} \mathrm{C}$ and extension at $72{ }^{\circ} \mathrm{C}$ for $1.5 \mathrm{~min}(7.5 \mathrm{~min}$ for cycle 35). The PCR products were diluted 1:30 with sterile double-distilled water. Then samples were subjected to nested PCR using the general primer pair R16F2n/R2 (5'-GAAACGACTGCTAAGACTGG-3'/5'TGACGGGTGTGTACAAACCCCG-3') (Gundersen and Lee 1996). The PCR conditions consisted of denaturation at $94{ }^{\circ} \mathrm{C}$ for $2 \mathrm{~min}$, followed by 35 cycles of denaturation at $94{ }^{\circ} \mathrm{C}(1 \mathrm{~min})$, annealing at $60{ }^{\circ} \mathrm{C}(1 \mathrm{~min})$ and primer extension at $72{ }^{\circ} \mathrm{C}$ for $1.5 \mathrm{~min}(7.5 \mathrm{~min}$ for cycle 35). PCR products from the direct and nested PCR were electrophoresed on $1.5 \%$ agarose gel stained with ethidium bromide.

Nested PCR products were sequenced at Macrogen (Korea) using R16R2 and R16F2n primers. The forward and backward sequences of each sample were aligned and edited using Chromas Pro (version 1.41; Technelysium Pty Ltd, Brisbane, QLD, Australia). Then the resulting sequences were compared with reference sequences deposited at the National Center for Biotechnology Information using Mega 5 (Tamura et al. 2011). A phylogenetic tree was generated based on the matrix of pairwise distances using the Kimura 2 parameter evolutionary model (Mega 5), with 1000 replications and 50\% bootstrap criteria (Hodgetts et al. 2008).

\section{Analysis of nitrogen in leaf samples}

About $5 \mathrm{~g}$ of acid lime leaves from each sample were washed and freeze dried. Then, the dried leaves were ground to fine powder. Kjeldahl digestion method was used to determine the amount of $\mathrm{N}$ (Persson et al. 2008). About $3.5 \mathrm{ml}$ of sulfuric acid was added to $0.1 \mathrm{~g}$ leaf sample. After that $3.5 \mathrm{~g} \mathrm{~K}_{2} \mathrm{SO}_{4}$ mixed with $0.4 \mathrm{~g} \mathrm{CuSo}_{4} \cdot 5 \mathrm{H}_{2} \mathrm{O}$ was added to the solution, followed by the addition of $3.5 \mathrm{~g} \mathrm{~K}_{2} \mathrm{SO}_{4}$ mixed with $\mathrm{Se}$. Then, the mixtures were heated on hotplate at $350{ }^{\circ} \mathrm{C}$ for $4 \mathrm{~h}$. Two blanks were prepared and treated as previously described. The digest was then analysed for total $\mathrm{N}$ using a Kjeltec Analyser.

\section{Analysis of sodium, potassium and calcium}

One gram of leaf sample was wet digested using $20 \mathrm{ml}$ $\mathrm{HNO}_{3}$ and $5 \mathrm{ml}$ of $\mathrm{H}_{2} \mathrm{O}_{2}$ for $30 \mathrm{~min}$ at $150{ }^{\circ} \mathrm{C}$. The final volume of the digested sample was made up to $50 \mathrm{ml}$ in a volumetric flask using deionized distilled water (DDW). 
The samples were analyzed in triplicates (Ahmad et al. 2008; Jilani et al. 2012). The $\mathrm{Na}, \mathrm{K}$ and $\mathrm{Ca}$ were analyzed using flame photometer (Sheerwood 450 flame photometer).

\section{Analysis of other macro and micro elements}

Analysis of other macro and micro elements (B, P, Zn, $\mathrm{Mg}, \mathrm{Fe}, \mathrm{Cu}$ ) in leaf samples was done following a modified protocol of Mihaylova et al. (2013). One gram of leaf sample was digested using $30 \mathrm{ml} \mathrm{HNO}_{3}$ and $10 \mathrm{ml}$ of $\mathrm{HCl}$ for $30 \mathrm{~min}$ at $300{ }^{\circ} \mathrm{C}$. The final volume of the digested sample from leaf samples was made up to $50 \mathrm{ml}$ and $100 \mathrm{ml}$, respectively using DDW. The diluted mixtures were filtered by $0.45 \mu \mathrm{l}$ filter membrane. Prepared samples were analyzed by inductively coupled plasma analysis (ICP-MS).

\section{Statistical analysis}

The mean values of minerals leaf samples were analyzed for statistical differences using Tukey's Studentized range test (SAS, v8, SAS Institute Inc., Cary, NC, USA).

\section{Results}

\section{Identification of phytoplasma}

Detection of phytoplasma in the 14 samples revealed presence of phytoplasma in all the symptomatic samples and asymptomatic samples from the six infected trees. No phytoplasma was detected in the disease-free uninfected trees. Direct and nested PCR resulted in the production of $1.8 \mathrm{k}$ base pair and $1.25 \mathrm{kbp}$ fragments, representing the 16S-23S rRNA gene and 16S rRNA gene of phytoplasma, respectively.

Analysis of 12 sequences representing the 16S rRNA gene of 12 samples showed that all sequences share 99.5-100 \% sequence similarity to each other and also to a previously deposited sequence of ' $\mathrm{C}$. Phytoplasma aurantifolia' from lime (EF186828) (Fig. 2). The 16S rRNA sequences of the 12 samples were deposited at European Nucleotide Archive under the accession numbers listed in Table 1.

\section{Mineral analysis in leaves}

Mineral analysis showed that there is no significant difference in the concentration of minerals between the uninfected leaf samples and the infected leaf samples which are not developing typical symptoms of WBDL $(\mathrm{P}>0.05)$. However, the concentration of $\mathrm{Na}$ was found to be significantly higher by four times in the infected leaves developing typical symptoms of WBDL (3008 ppm) compared to the infected but asymptomatic leaves $(757 \mathrm{ppm})$ collected from the same trees (Fig. 3; $\mathrm{P}<0.05$ ). The concentration of $\mathrm{Na}$ in the uninfected samples was found to be $570 \mathrm{ppm}$, falling within the range of the asymptomatic leaves which are infected by phytoplasma. The concentration of $\mathrm{P}$ and $\mathrm{K}$ also followed the same trend as $\mathrm{Na}$, but the concentrations were significantly higher by 1.6 times for $\mathrm{P}$ and 1.5 times for $\mathrm{K}$ in the symptomatic leaves compared to the asymptomatic leaves and the uninfected leaves (Fig. 3; $\mathrm{P}<0.05$ ).

On the other hand, the concentrations of $\mathrm{Ca}$ and $\mathrm{B}$ followed an opposite trend to that of $\mathrm{Na}, \mathrm{P}$ and $\mathrm{K}$. The concentrations of $\mathrm{Ca}$ and $\mathrm{B}$ were significantly lower by 1.2 and 1.8 times, respectively, in the symptomatic leaves compared to the asymptomatic leaves and the uninfected leaves (Figs. 3, 4). There were no significant differences between the symptomatic and asymptomatic leaves in the levels of $\mathrm{N}, \mathrm{Mg}, \mathrm{Fe}, \mathrm{Cu}$, and $\mathrm{Zn}$ (Figs. 3, 4).

Analysis of minerals in lime leaves showed that the uninfected and infected acid lime leaves have higher levels of N compared to standards described by Yen (1972) and Obreza et al. (2004) (Fig. 3). The level of $\mathrm{Na}$ was within the standard range for the asymptomatic leaves as well as the uninfected leaves. However, the level of $\mathrm{Na}$ was excess in infected leaves developing symptoms of WBDL. The levels of B and $\mathrm{Zn}$ in the uninfected and asymptomatic leaves were within the standards. The levels of $\mathrm{P}, \mathrm{K}, \mathrm{Ca}, \mathrm{Mg}, \mathrm{Fe}$, and $\mathrm{Cu}$ were below the satisfactory range in the uninfected, symptomatic and asymptomatic leaves (Figs. 3, 4).

\section{Discussion}

Mineral analysis showed that the level of $\mathrm{Na}$ in the asymptomatic leaves as well as the uninfected leaves was within the acceptable levels. However, symptomatic leaves of acid limes accumulated approximately 4 times more $\mathrm{Na}, 1.6$ times more $\mathrm{P}$ and 1.5 times more $\mathrm{K}$ compared to the asymptomatic leaves of the same trees. The accumulated levels of $\mathrm{Na}$ were above the recommended limit of $1500 \mathrm{ppm}$ (Obreza et al. 2004), reaching $3008 \mathrm{ppm}$. Excess amounts of Na may result in defoliation, leaf burn and dieback (Storey and Walker 1999), which have already been observed and reported in phytoplasma infected acid limes in Oman (Chung et al. 2006a). Thus the accumulation of $\mathrm{Na}$ in the symptomatic leaves appears to play a role in defoliation and dieback symptoms due to WBDL. This appears to be the first record of accumulation of $\mathrm{Na}$ in the symptomatic branches of acid limes infected by ' $\mathrm{C} a$. Phytoplasma aurantifolia'. Future studies are required to investigate the mechanisms driving the accumulation of $\mathrm{Na}$ in the symptomatic branches of WBDL infected limes. The levels of P and K also increased in the symptomatic leaves, but they were still below the recommended levels in leaves (Yen 1972; Obreza et al. 2004). Mohan and Rao (1986) reported that $\mathrm{P}$ accumulated in high amount in banana with bunchy top disease compared to healthy plants. Potassium is 


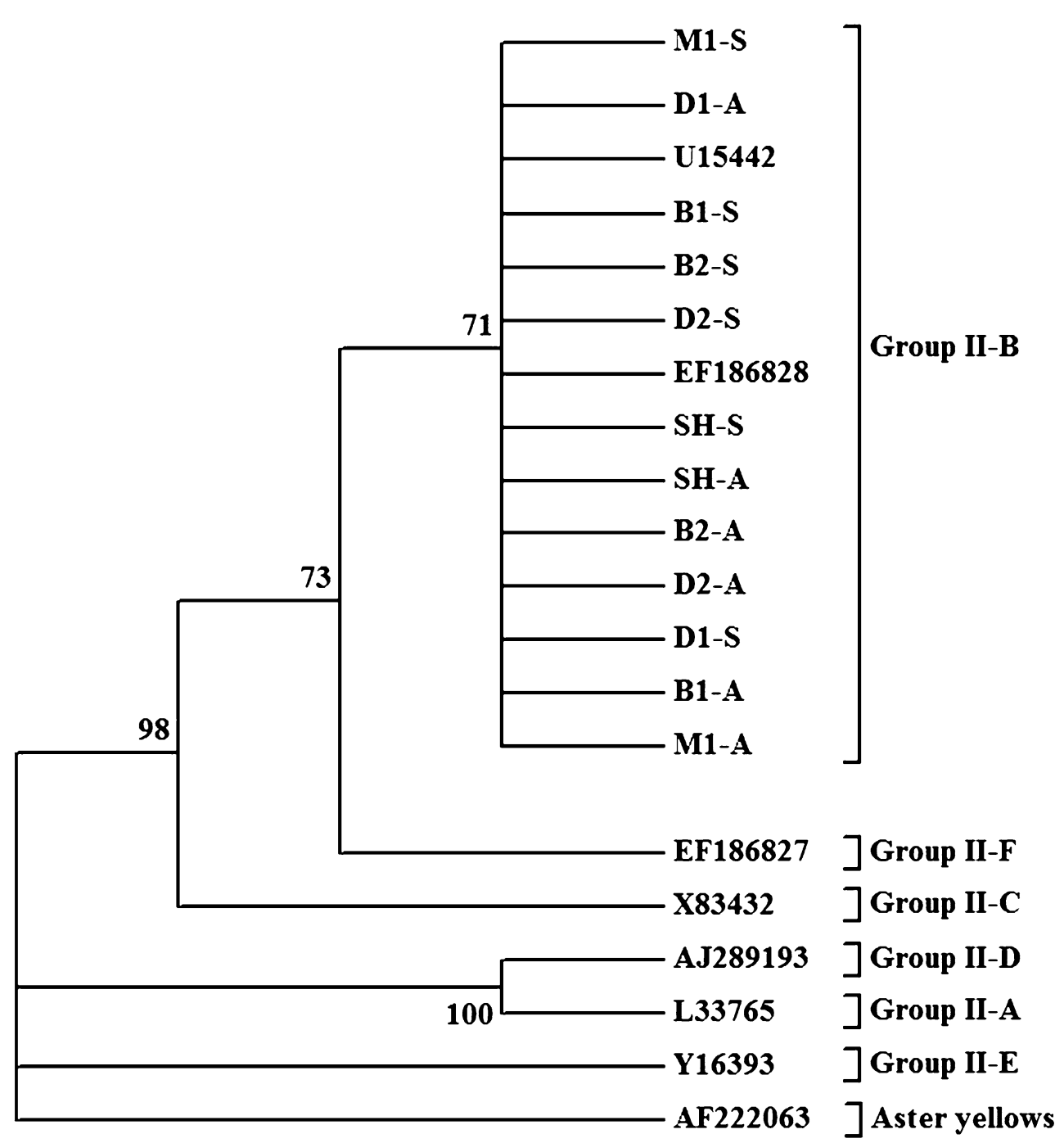

Fig. 2 Phylogram representing the relationship of 12 phytoplasma isolates from Oman to 2 reference 'Candidatus Phytoplasma aurantifolia' accessions (U15442 and EF186828) from the 16S rRNA Group II-B and to other phytoplasma groups. The tree was rooted to aster yellows phytoplasma (AF222063). The 16S rRNA sequences of isolates from Oman were submitted to the European Nucelotide Archive under the accession numbers listed in Table 1. Numbers within the tree represent the bootstrap values (values above $70 \%$ are indicated; 1000 replications). The tree is rooted to ' $C a$. P. asteris' (16Srl) (Aster yellows) as outgroup

essential for basic physiological functions such as the formation of sugars and starch, synthesis of proteins, and cell division and growth. It is also important in fruit formation and enhances fruit flavor, size and color. Potassium also helps to normalize the $\mathrm{CO}_{2}$ supply to citrus trees by controlling the opening and closing of stomata. Therefore, the rate of photosynthesis drops sharply when plants are $\mathrm{K}$ deficient. Potassium increases plant resistance to disease, size and quality of fruit and winter hardiness (Obreza 2003).

Findings from this study showed that symptom development due to WBDL was associated with significant reductions in the concentrations of $\mathrm{Ca}$ and $\mathrm{B}$ by 1.2 and 1.8 times, respectively. Calcium is an essential part of cell walls and membranes, and must be present for formation of new cells. The ratio of $\mathrm{Ca}$ and $\mathrm{K}$ was reported by McNew (1953) as important factor in the mobilization of cationic nutrients. In addition, it was observed that potato scab infection increased as supplies of $\mathrm{Ca}$ were increased in the presence of inadequate supply of $\mathrm{K}$ (McNew 1953). Boron deficiency was reported to result in dieback symptoms (Chapman 1989), which has been observed on lime trees infected by phytoplasma in Oman (Al-Sadi et al. 2012). 


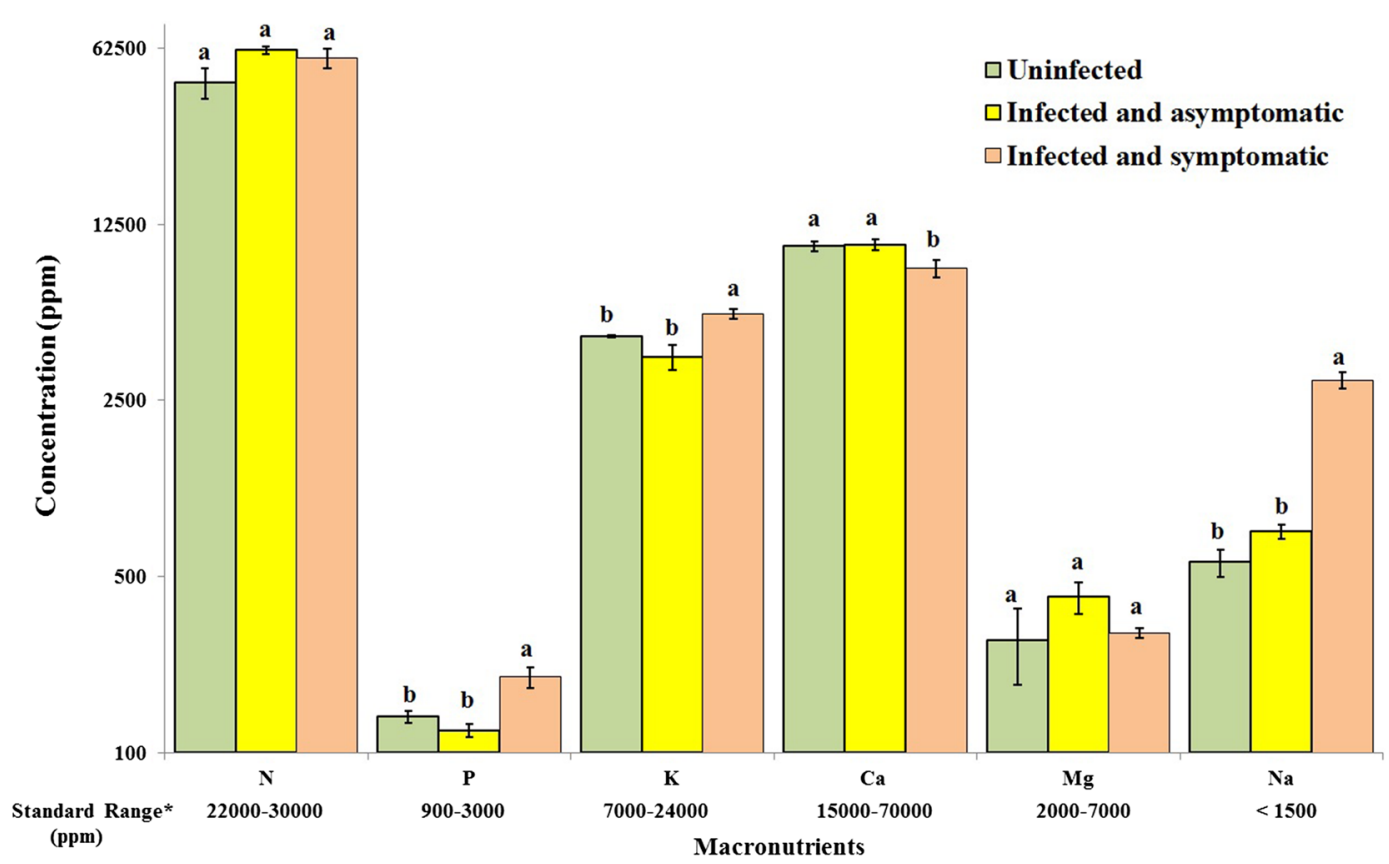

Fig. 3 Macro-element composition of uninfected, infected asymptomatic and infected symptomatic acid lime leaves. The data below the figure represent the standard range of elements according to (Yen 1972) and (Obreza et al. 2004). Values with the same letter in the same mineral category are not significantly different from each other at $\mathrm{P}<0.05$ (Tukey's Studentized range test, SAS). The $Y$-axis is logarithmic scale. The number of biological and technical replicates was 2 and 5 for the control, 6 and 18 for the infected asymptomatic leaves and 6 and 18 for the infected symptomatic leaves, respectively

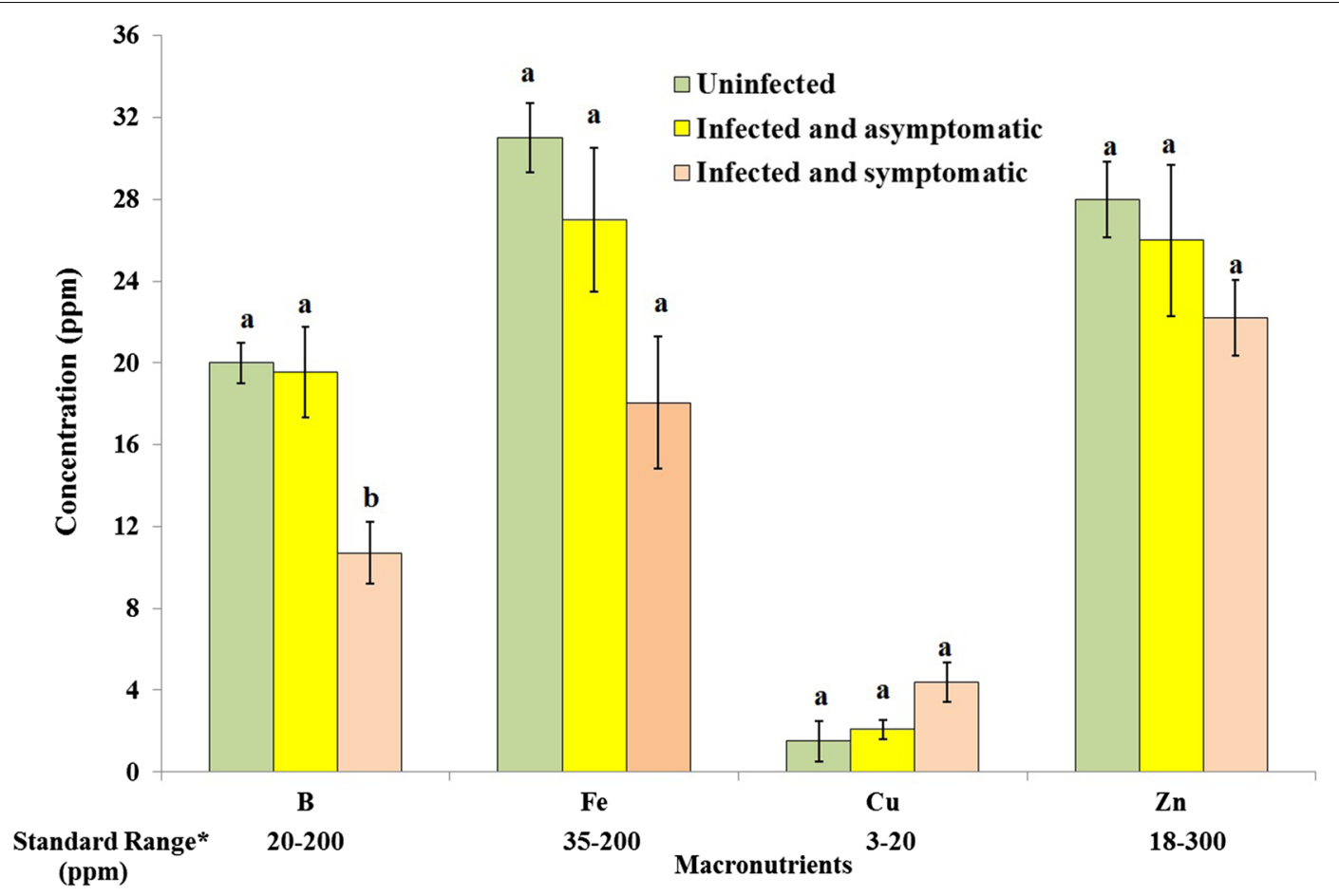

Fig. 4 Micro-element composition of uninfected, infected asymptomatic and infected symptomatic acid lime leaves. The data below the figure represent the standard range of elements according to (Yen 1972) and (Obreza et al. 2004). Values with the same letter in the same mineral category are not significantly different from each other at $\mathrm{P}<0.05$ (Tukey's Studentized range test, SAS). The number of biological and technical replicates was 2 and 5 for the control, 6 and 18 for the infected asymptomatic leaves and 6 and 18 for the infected symptomatic leaves, respectively 
No significant differences were found between symptomatic and asymptomatic leaves in the levels of $\mathrm{N}, \mathrm{Mg}, \mathrm{Cu}$, $\mathrm{Fe}$ and $\mathrm{Zn}$. This suggests the lack of influence of symptom development due to WBDL on these minerals. However, the levels of $\mathrm{N}$ were generally high compared to standard levels in citrus leaves. Excessive $\mathrm{N}$ levels cause nitrogen toxicity and leaves eventually turn yellow or brown and fall off (Purcino et al. 2007).

Mineral analysis in acid lime leaves, especially the uninfected leaves, revealed that the levels of $\mathrm{P}, \mathrm{K}, \mathrm{Ca}$, $\mathrm{Mg}, \mathrm{Fe}$ and $\mathrm{Cu}$ are different from the standards reported by Yen (1972) and Obreza et al. (2004). Han et al. (2011) reported that the concentration of minerals in plant leaves can vary according to climate, soil type and plant functional type. In addition, the majority of growers in Oman use animal manures for fertilizing the acid lime trees, without paying attention to the exact amounts of minerals required by acid limes. It is therefore likely that a combination of these factors affected the levels of minerals in acid lime leaves in Oman.

\section{Conclusion}

This study is the first to characterize the relationship between symptom development and mineral concentration in acid limes infected by ' $\mathrm{Ca}$. Phytoplasma aurantifolia'. Development of symptoms due to WBDL was found to be associated with mineral imbalance, especially on the levels of $\mathrm{Na}$ in the symptomatic leaves. Future studies should address the mechanisms driving the mineral imbalance in acid limes developing symptoms of WBDL. Further research is required to elucidate the roles of significantly affected minerals in the susceptibility/resistance of acid limes to "Ca. Phytoplasma aurantifolia", and to determine how strategies might be developed to overcome such changes using chemicals or other treatment of lime trees.

\section{Authors' contributions}

Designed the experiments: AMA, AGA, MAH; Performed the experiments: AGA MAH, WMA. Analyzed the data: AMA, AGA, MAH, WMA. Contributed reagents/ materials: AMA. Wrote the manuscript: AMA, AGA, MAH, WMA. All authors read and approved the final manuscript.

\section{Author details}

${ }^{1}$ Department of Crop Sciences, College of Agricultural and Marine Sciences, Sultan Qaboos University, Muscat, Oman. ${ }^{2}$ Department of Chemistry, University of Agriculture, Faisalabad 38040, Pakistan.

\footnotetext{
Acknowledgements

Thanks are due to Sultan Qaboos University for financial support to the study through the strategic Project SR/AGR/CROP/13/01. Authors would like to acknowledge Mr. Issa Al-Mahmooli, and Mr. Khalid Al-Hashmi for technical help.
}

\section{Competing interests}

The authors declare that they have no competing interests.

Received: 11 January 2016 Accepted: 24 March 2016

Published online: 06 April 2016

\section{References}

Ahmad I, Hanif MA, Nadeem R, Jamil MS, Zafar MS (2008) Nutritive evaluation of medicinal plants being used as condiments in South Asian Region. J Chem Soc Pak 30(3):400-405

Al-Sadi AM, Al-Moqbali H, Al-Yahyai R, Al-Said F, Al-Mahmooli I (2012) AFLP data suggest a potential role for the low genetic diversity of acid lime (Citrus aurantifolia) in Oman in the outbreak of witches' broom disease of lime. Euphytica 188:285-297

Al-Yahyai R, Al-Subhi A, Al-Sabahi J, Al-Said F, Al-Wahaibi AK, Al-Sadi AM (2014a) Chemical composition of acid lime leaves infected with Candidatus Phytoplasma aurantifolia. Agric Sci 5:66-70

Al-Yahyai R, Al-Subhi A, Al-Sabahi J, Al-Said F, Al-Wahaibi K, Al-Sadi AM (2014b) Chemical composition of acid lime leaves infected with Candidatus Phytoplasma aurantifolia. Agric Sci 5(1):66-70. doi:10.4236/as.2014.51007

Ammar E, Hogenhout S (2006) Mollicutes associated with arthropods and plants. Insect symbiosis 2:97-118

Baxter IR, Gustin JL, Settles AM, Hoekenga OA (2013) Ionomic characterization of maize kernels in the intermated B73 $\times$ Mo17 population. Crop Sci 53:208-220

Baxter IR, Ziegler G, Lahner B, Mickelbart MV, Foley R, Danku J, Armstrong P, Salt DE, Hoekenga OA (2014) Single-kernel ionomic profiles are highly heritable indicators of genetic and environmental influences on elemental accumulation in maize grain (Zea mays). PLoS ONE 9:e87628

Bertaccini A (2007) Phytoplasmas: diversity, taxonomy, and epidemiology. Front Biosci 12:673-689

Bertaccini A, Duduk A (2009) Phytoplasma and phytoplasma diseases: a review of recent research. Phytopathol Mediter 48:355-378

Bertaccini A, Duduk B, Paltrinieri S, Contaldo N (2014) Phytoplasmas and phytoplasma diseases: a severe threat to agriculture. Am J Plant Sci 5:1763-1788

Bové J, Garnier M (2002) Phloem-and xylem-restricted plant pathogenic bacteria. Plant Sci 163(6):1083-1098

Chapman HD (1989) The mineral nutrition of citrus. In: Reuther W, Batchelor LD, Webber HJ (eds) The citrus industry: anatomy, physiology, genetics and reproduction, vol 2. University of California, USA

Chung KR, Khan IA, Brlansky RH (2006a) Citrus diseases exotic to Florida: Witches' Broom Disease of Lime (WBDL). Plant Pathology Department, Florida Cooperative Extension Service, Institute of Food and Agricultural Sciences, University of Florida: Fact Sheet PP228

Chung KR, Khan IA, Brlansky RH (2006b) Citrus diseases exotic to Florida: witches' broom disease of lime (WBDL). EDIS Publications, University of Florida, Gainesville PP228, pp 1-3

De Oliveira E, Magalhães PC, Gomide RL, Vasconcelos CA, Souza IRP, Oliveira CM, Cruz I, Schaffert RE (2002) Growth and nutrition of mollicute-infected maize. Plant Dis 86:945-949

De Oliveira E, De Oliveira CM, Magalhães PC, De Andrade CDLT, Hogenhout SA (2005) Spiroplasma and phytoplasma infection reduce kernel production, and nutrient and water contents of several but not all maize cultivars. Maydica 50:171-178

Deng S, Hiruki C (1991) Amplification 16S rRNA genes from culturable and non-culturable mollicutes. J Microbiol Methods 14:53-61

Doyle J, Doyle JL (1990) Isolation of plant DNA from fresh tissue. Focus 12:13-15

Gundersen DE, Lee IM (1996) Ultrasensitive detection of phytoplasmas by nested PCR assay using two universal primer pairs. Phytopathol Mediterr 35:144-151

Han WX, Fang JY, Reich PB, lan Woodward F, Wang ZH (2011) Biogeography and variability of eleven mineral elements in plant leaves across gradients of climate, soil and plant functional type in China. Ecol Lett 14(8):788796. doi:10.1111/j.1461-0248.2011.01641.x

Hill G, Sinclair W (2000) Taxa of leafhoppers carrying phytoplasmas at sites of ash yellows occurrence in New York State. Plant Dis 84(2):134-138

Hodgetts J, Boonham N, Mumford R, Harrison N, Dickinson M (2008) Phytoplasma phylogenetics based on analysis of secA and 235 rRNA gene sequences for improved resolution of candidate species of 'Candidatus Phytoplasma'. Int J Syst Evol Microbiol 58:1826-1837

Hogenhout SA, Oshima K, Ammar ED, Kakizawa S, Kingdom HN, Namba S (2008) Phytoplasmas: bacteria that manipulate plants and insects. Mol Plant Pathol 9(4):403-423 
Jilani MI, Ahmad MI, Hanif R, Nadeem R, Hanif MA, Khan MA, Ahmad I, lqbal $\mathrm{T}$ (2012) Proximate analysis and mineral profile of three elite cultivars of Rosa hybrida flowers. Pak J Bot 44(5):1711-1714

Lee IM, Davis RE, Gundersen-Rindal DE (2000) Phytoplasma: phytopathogenic mollicutes. Annu Rev Microbiol 54:221-255

McNew GL (1953) The effects of soils fertility. In: Steffirud A (ed) Plant disease: the yearbook of agriculture. United States Department of Agriculture, Washington, DC, pp 101-114

Mihaylova V, Lyubomirova V, Djingova R (2013) Optimization of sample preparation and ICP-MS analysis for determination of 60 elements for characterization of the plant ionome. Int J Environ Anal Chem 93:1441-1456

Mohan NK, Rao VNM (1986) Distribution of $\mathrm{P}^{32}$ in healthy and bunchy top diseased Robusta banana. J Agric Sci 56:152-157

Obreza TA (2003) Importance of potassium in a Florida citrus nutrition program. Better Crops 87(1):19-22

Obreza TA, Zekri M, Hanlon EA, Morgan K, Schumann A, Rouse R (2004) Soil and leaf tissue testing for commercial citrus production. University of Florida Cooperative Extension Service SL253.04

Persson J-Å, Wennerholm M, O'Halloran S (2008) Handbook for Kjeldahl Digestion: a recent review of the classical method with improvements developed by FOSS. FOSS, Hilleroed

Purcino RP, Medina CL, de Souza DM, Winck FV, Machado EC, Novello JC, Machado MA, Mazzafera P (2007) Xylella fastidiosa disturbs nitrogen metabolism and causes a stress response in sweet orange Citrus sinensis cv. Pêra. J Exp Bot 58(11):2733-2744. doi:10.1093/jxb/erm138
Rossi G, Beni C, Socciarelli S, Marconi S, Pastore M, Del Vaglio M, Gervasi F (2010) Mineral nutrition of pear and apricot trees cultivated in Southern Italy area damaged by phytoplasma microorganisms. Acta Horticulturae 868:433-438

Schneider B, Seemüller E, Smart CD, Kirkpatrick BC (1995) Phylogenetic classification of plant pathogenic mycoplasmalike organisms or phytoplasmas. In: Raszin S, Tully JG (eds) Molecular and diagnostic procedures in mycoplasmology, vol 2. Academic Press, New York, pp 369-380

Storey R, Walker RR (1999) Citrus and salinity. Sci Hortic 78(1-4):39-81. doi:10.1016/s0304-4238(98)00190-3

Sugio A, Hogenhout SA (2012) The genome biology of phytoplasma: modulators of plants and insects. Curr Opin Microbiol 15(3):247-254

Sugio A, MacLean AM, Kingdom HN, Grieve VM, Manimekalai R, Hogenhout SA (2011) Diverse targets of phytoplasma effectors: from plant development to defense against insects. Annu Rev Phytopathol 49:175-195

Tamura K, Peterson D, Peterson N, Stecher G, Nei M, Kumar S (2011) MEGA5: molecular Evolutionary Genetics Analysis using Maximum Likelihood, Evolutionary Distance, and Maximum Parsimony Methods. Mol Biol Evol 28:2731-2739

Yen MJ (1972) Leaf analysis as a guide to fertilization of citrus tree. Agric Res 21:250-255

Zhao J, Liu MJ (2009) Variation of mineral element contents in Chinese jujube with witches' broom disease. Acta Hortic 840:399-404

\section{Submit your manuscript to a SpringerOpen ${ }^{\odot}$ journal and benefit from:}

- Convenient online submission

- Rigorous peer review

- Immediate publication on acceptance

- Open access: articles freely available online

- High visibility within the field

- Retaining the copyright to your article

Submit your next manuscript at $>$ springeropen.com 